\title{
IMPLEMENTASI KEBIJAKAN PEMUNGUTAN PAJAK REKLAME KOTA MALANG
}

\author{
Abd. Rohman, Vicky Eka Fiona Hendrawan, Sugeng Rusmiwari \\ Program Studi Admnistrasi Publik, Fakultas Ilmu Sosial dan Politik \\ Universitas Tribhuwana Tunggadewi \\ Email: rohmanch93@yahoo.com
}

\begin{abstract}
Abstrak: Bertambahnya jumlah usaha-usaha yang ada di kota Malang berdampak pada jumlah penggunaan reklame yang semakin meningkat dari tahun ketahun. Tujuan penelitian ini untuk mengetahui dan menganalisis implementasi kebijakan pemungutan pajak reklame berdasarkan Peraturan Daerah (Perda) Kota Malang serta mengetahui faktor penghambat dan pendukungnya. Jenis penelitian yang di gunakan adalah deskriptif kualitatif dengan tehnik pengumpulan data melalui wawancara, observasi dan dokumentasi. Analisis data menggunakan model Miles dan Huberman, yakni reduksi data, penyajian data dan penarikan kesimpulan dan verifikasi. Kebasahan data menggunakan triangulasi tehnik. Hasil penelitian menunjukkan bahwa implementasi kebijakan pemungutan pajak reklame di Kota Malang dengan menerapkan sistem official assessment, mekanisme pembayaran yang dilakukan oleh wajib pajak dengan membawa blanko Surat Pemberitahuan Pajak Daerah (SPTPD) dan tarifnya ditentukan dari nilai sewa reklame $\mathrm{x}$ dan tarif pajak reklame. Kebijakan mengenai intensifikasi yaitu mengenai pengawasan pembayaran pajak oleh wajib pajak, peningkatan kualitas sumber daya manusia dan penyusunan peraturan. Kebijakan terkait dengan ekstensifikasi yaitu mengenai pendataan wajib pajak baru dan sosialisasi pajak reklame. Faktor pendukung penerimaan pajak reklame di Kota Malang yaitu meliputi 1) Sarana dan Prasarana 2) Sistem informasi yang mendukung dan 3) kondisi perekonomian yang semakin membaik. Faktor Penghambat yaitu meliputi 1) rendahnya kesadaran wajib pajak 2) Kualitas Aparatur Dispenda Kota Malang dan 3) Adanya perubahan sistem media reklame yang digunakan dan harus beralih menggunakan reklame berbentuk videotron.
\end{abstract}

\section{Kata kunci: Kebijakan; Pajak; Reklame}

Abstract: The increasing quantity of business in Malang City has an impact of increased using advertisement from year to year. This study's purpose was to know and analyze the implementation of advertisement tax collection policies based on the Regional Regulation (Perda) of Malang City and to know the obstacle and supporting factors. This research type was using descriptive qualitative and data collection techniques used interviews, observation and documentation. Data analysis used Miles \& Huberman model, that's data reduction, presentment, making conclusions and verification. Validity of the data used triangulation techniques. The results showed that the implementation of the advertisement tax collection policy in Malang City by applying an official assessment system, the payment mechanism made by the taxpayer bringing a blank Local Tax Return (SPTPD) and the rate is determined from the rent value advertisement $x$ and the advertisement tax rate. Policies about intensification, these are regarding supervision of tax payments by taxpayers, improving the quality of human resources and making regulations. Policies related to extensification are about new taxpayers collection and socialization of advertisement tax. Supporting factors of advertisement tax revenue in Malang include 1) Facilities and Infrastructure 2) Supporting information systems and 3) improving economic conditions. The obstacle include 1) low awareness of taxpayers 2) Quality of Malang City's Apparatus and 3) There is a change in the advertising media system used and must switch to using videotron advertisements.

Keywords: Policy; Tax; Advertisement 


\section{PENDAHULUAN}

Salah satu kewajiban negara adalah memberikan pelayanan yang layak bagi rakyatnya dalam memenuhi kebutuhan hidup dan pencapaian keinginan-keinginannya. Pelayanan yang baik dapat dilihat dan dinilai dari pelaksanaan yang sesuai dengan standar pelayanan. Pemberian pelayanan saat ini masih sering dirasakan jauh dari harapan masyarakat. Memprihatinkan lagi, masyarakat sama sekali tidak memahami secara pasti tentang pelayanan yang seharusnya diterima dan sesuai dengan prosedur (Pebriani \& Rohman, 2019).

Negara Indonesia menganut sistem pemerintahan, dimana daerah diberikan kewenangan untuk mengatur, mengelola dan menengani rumah tangganya sendiri demi mencapai kesejahteraan. Kewenangan yang diberikan mencakup banyak hal, mulai dari bidang politik, pemerintahan, ekonomi, keuangan, dan lainnya. Sistem ini kemudian disebut dengan otonomi daerah dengan tiga asas pokok, sebagaimana tertuang dalam Undang-Undang No. 32 Tahun 2004, yaitu asas desentralisasi, dekonsentrasi, dan asas perbantuan.

Selanjutnya UU No. 32 Tahun 2004 tentang otonomi daerah ini diperbaharui dengan UU No. 9 Tahun 2015. Dalam UU tersebut menjelaskan bahwa Otonomi Daerah adalah hak, wewenang, dan kewajiban daerah otonom untuk mengatur dan mengurus sendiri urusan pemerintahan dan kepentingan masyarakat setempat sesuai dengan peraturan perundangundangan yang berlaku. Agar pemerintah daerah dapat melakukan manajemen pendapatan secara optimal, hal pertama yang perlu diperhatikan adalah mengenali sumber-sumber pendapatan daerah.

Sumber pendapatan daerah diupayakan melalui pajak daerah dan retribusi. Dalam upaya melakukan pembangunan, salah satu usaha pemerintah daerah adalah dengan menyerap pendapatan daerah dengan maksimal, baik dari pajak daerah maupun retribusi daerah seperti tersebut di atas. Pendapatan Asli Daerah (PAD) merupakan sumber pendapatan daerah yang berasal dari kegiatan ekonomi daerah itu sendiri yang juga merupakan salah satu pilar kemandirian suatu daerah. Upaya untuk meningkatkan pendapatan daerah salah satunya yaitu mengoptimalkan sumber daya daerah yang sudah ada, misalnya dengan mengoptimalkan penerimaan dari pajak daerah.

Pajak daerah merupakan salah satu sumber pendapatan daerah yang sangat penting guna membiayai penyelenggaraan pemerintahan dan pembangunan daerah dalam melaksanakan pelayanan kepada masyarakat serta mewujudkan kemandirian daerah. Pajak daerah terdiri dari pajak hotel, pajak restoran, pajak hiburan pajak reklame, pajak penerangan jalan, dan lain-lain sesuai dengan Undang-Undang Nomor 34 Tahun 2000.

Pajak reklame adalah pajak atas penyelenggaraan reklame. Pajak reklame dikenakan dengan alasan bahwa reklame dipergunakan untuk memperkenalkan, menganjurkan atau memujikan suatu barang, jasa atau orang yang ditempatkan atau yang dapat dilihat, dibaca, dan didengarkan dari suatu tempat umum, kecuali yang dilakukan oleh pemerintah. Sistem pemungutan pajak ada tiga yaitu offisial assessment system, yaitu sistem pemungutan pajak yang memberi wewenang kepada pemerintah (fiskus) untuk menentukan besaran pajak yang terutang oleh wajib pajak. Self assessmen system adalah sistem pemungutan pajak yang memberi wewenang kepada wajib pajak untuk menetapkan sendiri besaran pajak yang terutang, dan witholding system adalah salah satu cara pembayaran pajak yang dilakukan melalui pihak terkait yang ditunjuk.

Indonesia menganut self assessment system yaitu wajib pajak diberi kepercayaan untuk menghitung, membayar dan melaporkan sendiri pajak yang terhutang (self assessment system), maka di sini tidak diperlakukan surat ketetapan pajak. Fiskus dalam hal ini aparat Direktorat 
Jendral Pajak/Pemerintah Daerah hanya menjalankan fungsi pembinaan, penelitian, pengawasan dan penerapan sanksi administrasi perpajakan. Penagihan pajak dalam sistem self assessment system dilaksanakan sedini mungkin sejak timbulnya hutang pajak atau sebelum tanggal jatuh tempo pembayaran atau penyetoran pajak. Kebijakan tersebut juga dilaksanakan dalam proses pemungutan pajak reklame.

Kota Malang terkenal dengan sebutan kota pendidikan, memiliki berbagai fasilitas pendidikan sangat memadai. Malang juga disebut sebagai kota wisata yang memiliki banyak lokasi wisata menarik dan beraneka ragam kuliner. Maraknya bisnis yang dijalankan di kota Malang ini sangat membutuhkan promosi agar menarik banyak pengunjung atau konsumennya. Salah satu media promosi yang digunakan oleh pebisnis tersebut yaitu reklame. Jenis reklame yang ditawarkan kepada masyarakat sangat beragam sesuai dengan kebutuhan masing-masing.

Bertambahnya jumlah usaha-usaha yang ada di kota Malang berdampak pada jumlah penggunaan reklame yang semakin meningkat dari tahun ketahun. Kenaikan penggunaan reklame pastinya diikuti dengan peningkatan jumlah target dan realisasi penerimaan pajak reklame di kota Malang. Selama tahun 2013 sampai dengan 2015, target penerimaan pajak reklame yang ditetapkan mengalami kenaikan dan penurunan dengan realisasi penerimaan pajak reklame yang melampaui jumlah yang telah ditargetkan, hal ini sesuai dengan data yang disajikan pada tabel berikutut ini:

Tabel: Target dan Realisasi Penerimaan Pajak Reklame Kota Malang Tahun 2013-2015

\begin{tabular}{|c|c|c|c|}
\hline Tahun & Target & Realisasi & Pencapaian (\%) \\
\hline 2013 & $9.037 .246 .651,74$ & $10.716 .211 .079,75$ & $118,58 \%$ \\
\hline 2014 & $15.640 .433 .942,58$ & $19.390 .018 .667,52$ & $123,97 \%$ \\
\hline 2015 & $18.676 .522 .723,99$ & $19.557 .043 .020,32$ & $104,71 \%$ \\
\hline
\end{tabular}

Sumber: Dinas Pendapatan Daerah Kota Malang, 2016.

Tabel tersebut menunjukkan bahwa presentase pencapaian target dan realiasasi mengalami kenaikan pada tahun 2014, kemudian mengalami penurunan presentase pada tahun 2015. Penurunan tersebut disebabkan karena peningkatan target yang tidak di ikuti dengan dukungan kondisi ekonomi pada saat itu. Meskipun presentase dari tahun 2014 ke tahun 2015 menurun, bukan berarti pendapatan pajak daerah menurun, namun demikian penurunan tersebut terjadi karena adanya peningkatan target yang harus dicapai. Apabila dilakukan perbandingan realisasi tahun 2014 sampai 2015 menunjukkan adanya peningkatan yaitu sebesar Rp.167.024.352,80 atau sebesar 0,861\%.

Dari uraian di atas, menarik untuk dilakukan penelitian dan kajian lebih jauh terkait dengan implementasi pemungutan pajak reklame di Kota Malang untuk meningkatkan Pendapatan Asli Daerah (PAD) guna mewujudkan kemandirian daerah untuk memberikan pelayanan yang layak bagi warganya dalam memenuhi kebutuhan hajat hidupnya.

\section{METODE PENELITIAN}

Berdasarkan pada permasalahan yang telah diuraikan, penelitian ini menggunakan jenis penelitian deskriptif. Jenis penelitian deskriptif mendeskripsikan masalah dalam suatu kondisi, tata cara dalam situasi tertentu, hubungan antar-kegiatan, sikap serta proses yang berlangsung. Menurut Kountor (2004:105), "penelitian deskriptif (descriptive research) adalah jenis penelitian yang memberikan gambaran atau uraian atas suatu keadaan sejelas mungkin tanpa 
ada perlakuan terhadap objek yang diteliti." Sedangkan Nazir (2003:54) berpendapatan bahwa "penelitian dengan metode deskriptif adalah suatu metode dalam meneliti status kelompok manusia, suatu objek, suatu sel kondisi, suatu sistem pemikiran ataupun suatu kelas peristiwa pada masa sekarang." Digunakannya jenis penelitian ini adalah bertujuan untuk membuat deskripsi, gambaran secara sistematis, faktual dan aktual mengenai fakta-fakta, sifat-sifat serta hubungan antar fenomena yang diselidiki.

Penelitian ini menggunakan pendekatan kualitatif. Menurut Kountur (2004:16), pendekatan kualitatif adalah penelitian yang datanya adalah data kualitatif, umumnya dalam bentuk narasi atau gambar-gambar. Alasan peneiliti menggunakan pendekatan ini karena penelitian ini dimaksudkan untuk memahami fenomena-fenomena yang terjadi terkait dengan implementasi kebijakan pemungutan pajak reklame berdasarkan Peraturan Daerah (Perda) Kota Malang. Pengambilan data dilakukan dengan teknik wawancara, observasi langsung dan dokumentasi. Setelah data diperoleh, selanjutnya data dianalisis dengan menggunakan model Miles dan Huberman, yaitu reduksi data, penyajian data, dan penarikan kesimpulan dan verifikasi. Kebasahan data dalam penelitian ini menggunakan triangulasi tehnik.

\section{HASIL DAN PEMBAHASAN}

Pemungutan Pajak reklame di Kota Malang sebagian sudah menerapkan aplikasi elektronik atau yang disebut dengan $e$-tax. Sistem $e$-tax ini pada dasarnya diberlakukan untuk semua jenis pajak daerah yang ada di Kota Malang. Sampai saat ini penerapan $e$-tax di Kota Malang masih pada pajak reklame, hotel, hiburan, dan pajak parkir. Sistem pembayaran $e$-tax telah melibatkan Bank Jatim sebagai mitra pembayaran, data base yang masuk secara otomatis terkoneksi dengan database di Badan Pelayanan Pajak Daerah (BPPD) Kota Malang. Melalui sistem ini Wajib Pajak Pemerintah Daerah (WPPD) sudah tidak perlu lagi ke kantor BPPD utuk melaporkan pajaknya. WPPD secara online dapat menghitung, membayar, dan melaporkan kewajiban perpajakannya. WPPD sudah tidak perlu lagi membawa Surat Pemberitahuan Pajak Daerah (SPTPD) dan kasbonnya ke BPPD Kota Malang, semuanya sudah terintegrasi secara online. Penerapan $e$-tax tersebut sudah seharusnya memberikan kemudahan kepada WP Pajak Reklame dalam memenuhi kewajiban perpajakannya. Kondisi ini mendukung upaya optimalisasi Penerimaan Pajak Reklame Kota Malang yaitu yang dilakukan sebagai berikut:

\section{a. Intensifikasi}

1) Pengawasan pembayaran pajak oleh wajib pajak

Strategi peningkatan pengawasan pembayaran pajak daerah merupakan faktor penting dalam pencapaian penerimaan pajak daerah Kota Malang. Pengawasan yang baik akan meminimalkan penyelewengan pembayaran pajak oleh wajib pajak. Sistem pengelolaan yang terstruktur akan meminimalisir kecurangan yang terjadi.

2) Kualitas Aparatur BPPD Kota Malang

Kualitas SDM dalam suatu organisasi menentukan titik poin dari organisasi tersebut. Kualitas SDM yang baik akan menciptakan suasana kerja yang kondusif sehingga menghasilkan kinerja sesuai tujuan yang diharapkan. BPPD Kota Malang selalu melakukan pembenahan atau meng-upgrade SDM yang ada untuk menghasilkan SDM yang handal dan terampil dibidangnya khususnya pajak daerah. Kualitas SDM ditingkatkan melalui penegakan disiplin kerja aparatur BPPD serta keterampilan yang dimiliki.

3) Penyusunan Peraturan 
Peraturan hukum merupakan suatu landasan kokoh sebagai pijakan untuk terlaksananya suatu kegiatan. Landasan hukum pengelolaan pajak reklame Kota Malang adalah Perda Kota Malang Nomor 16 Tahun 2010 tentang Pajak Daerah. Selain itu saat ini juga telah diterbitkan Perwali Malang Nomor 20 Tahun 2013 tentang Tata Cara Pembayaran, Penyetoran, Tempat Pembayaran, Angsuran dan Penundaan Pembayaran Pajak Daerah. Secara teknis pelaksanaan dan peraturan $e$-tax belum sepenuhnya di atur secara spesifik dalam peraturan yang ada. Saat ini Pemerintah Kota Malang bersama BPPD Kota Malang sedang merumuskan kembali peraturan teknis tentang pelaksanaan $e$-tax pajak daerah di Kota Malang.

\section{b. Ekstensifikasi}

1) Pendataan Wajib Pajak Baru

Optimalisasi penerimaan pajak reklame di Kota Malang salah satunya di lakukan dengan program Ekstensifikasi, yaitu melalui pendataan wajib pajak. Cara ini dilakukan untuk meningkatkan penerimaan pajak reklame dengan terjun langsung ke lapangan. Berdasarkan hasil wawancara dapat diketahui bahwa pihak BPPD secara rutin melakukan survey lapangan minimal satu bulan sekali untuk melakukan pendataan baru. Hal ini dilakukan guna mengetahui atau mendata wajib pajak reklame baru.

2) Sosialisasi Pajak Reklame

Sosialisasi merupakan cara penyampaian informasi kepada masyarakat tentang himbauan atau promosi tertentu. Dalam rangka optimalisasi penerimaan pajak reklame, BPPD Kota Malang juga melakukan sosialisasi kepada masyarakat. Tingkat kesadaran masyarakat yang kurang terhadap pentingnya membayar pajak membuat BPPD Kota Malang selalu melakukan sosialisasi guna membangun kepercayaan masyarakat.

\section{Faktor Pendukung dan Penghambat}

a. Faktor Pendukung

1) Sarana dan Prasarana

Hasil wawancara diatas dapat diketahui bahwa tempat kerja BPPD Kota Malang saat ini sangat representatif dan nyaman untuk melakukan aktivitas kerja. Gedung kantor sangat memadai yang didukung dengan fasilitas lainnya seperti pendingin ruangan dan adanya koneksi internet. Alat tulis kantor juga lengkap sebagai sarana penujang terlaksananya kegiatan kerja, mulai dari alat tulis sampai media computer dan printer sebagai sarana input dan output data pajak daerah. Data penerimaan pajak sudah berbasis komputerisasi semua.

2) Sistem Informasi yang Mendukung

Hasil wawancara diatas dapat diketahui bahwa sistem IT yang telah diterapkan BPPD Kota Malang dalam pengelolaan Pajak Daerah khususnya Pajak Reklame adalah SIMPATDA (Sistem Manajemen Pajak Daerah Antar Bidang), dan E-Tax (Elektronik Tax). SIMPATDA merupakan data base pengelolaan pajak reklame dan pajak daerah lainnya yang terintegrasi dengan semua bidang di lingkup kerja BPPD Kota Malang.

3) Perekonomian yang semakin membaik

Dengan perekonomian masyarakat yang membaik maka daya konsumsi masyarakat akan meningkat pula hal ini membuka peluang usaha yang dilakukan oleh berbagai jenis usaha sehingga peningkatan potensi pada sektor ini dapat terwujud.

b. Faktor Penghambat

1) Rendahnya Kesadaran Wajib Pajak 
Pajak reklame merupakan pajak yang dikenakan terhadap masyarakat yang mempunyai usaha secara Peraturan Perundang-undangan diwajibkan untuk membayar iuran kepada kas daerah. Sumber penerimaan ini yang selalu dioptimalkan oleh Pemerintah Kota Malang khusunya BPPD Kota Malang melalui penjaringan wajib pajak baru dan berbagai upaya lainnya. Kesadaran bayar pajak yang kurang dari masyarakat menjadi tantangan bagi aparatur BPPD Kota Malang dalam meningkatkan penerimaan pajak daerah Kota Malang.

2) Kualitas Aparatur BPPD Kota Malang

Sumber Daya Manusia merupakan faktor utama terselenggaranya organisasi secara baik atau buruk. Sumber Daya Manusia yang mumpuni akan menghasilkan kinerja organisasi secara maksimal, tertata, dan rapi. Begitu pula sebaliknya. Sumber Daya Manusia yang buruk akan menciptakan iklim organisasi yang tidak sehat.

Hasil penelitian dapat memberikan gambaran mengenai implementasi kebijakan pemungutan pajak reklame berdasarkan Peraturan Daerah (Perda) Kota Malang, dimana implementasi kebijakan tersebut terkait dengan upaya untuk memaksimalkan pendapatan pajak reklame dengan potensi pajak yang dimiliki. Implementasi kebijakan dalam pemungutan pajak reklame juga dilakukan untuk memberikan pemahaman wajib pajak terhadap peraturan perpajakan yang telah ada.

Wajib pajak yang tidak memahami peraturan perpajakan secara jelas cenderung akan menjadi wajib pajak yang tidak taat. Umumnya masyarakat belum sepenuhnya dalam memiliki pemahaman terhadap keberadaan pajak karena masih merasa pembayaran pajak memberatkan, pembayarannya sering mengalami kesulitan, ketidak-mengertian masyarakat apa dan bagaimana pajak serta kesulitan dalam menghitung dan melaporkannya. Manfaat pajak yang dapat rasakan yaitu dengan pajak, uang yang dibayarkan kepada negara akan digunakan oleh negara untuk kebutuhan seluruh rakyat Indonesia.

Seharusnya para wajib pajak diberi pemahaman yang lebih mengenai manfaat pajak dan kemana uang pajak diguanakan melalui sosialisasi, serta dengan dilakukan pendekatan terhadap Wajib Pajak agar para Wajib Pajak lebih merasa dekat dan tidak takut membayar pajak. Selama ini, hal tersebut menjadi kendala sebagai penghambat dalam memaksimalkan perolehan pajak pada sektor tersebut. Kondisi ini menjadikan aktivitas pelaksanaan pemungutan pajak tidak berjalan sesuai dengan ketentuan. Dari itu, diperlukan suatu upaya pemahaman wajib pajak sehingga kesadaran masyarakat sebagai wajib pajak menjadi meningkat.

Menurut Zuraida (2012:59) yaitu pajak reklame adalah pajak yang kewenangan memungutnya diberikan kepada kota/kabupaten. Reklame adalah benda, alat, perbuatan atau media yang menurut bentuk dan corak ragamnya untuk tujuan komersial, dipergunakan untuk memperkenalkan, menganjurkan, atau memujikan suatu barang, jasa atau orang, ataupun untuk menarik perhatian umum kepada suatu barang, jasa atau orang yang ditempatkan atau yang dapat dilihat, dibaca dan atau didengar dari suatu tempat oleh umum, kecuali yang dilakukan oleh pemerintah.

Hasil penelitian ini juga didukung oleh hasil penelitian terdahulu yang dilakukan oleh Sripradita (2014) dimana semakin efektifnya pelaksanaan kebijakan terkait pengelolaan pajak, maka akan mendukung upaya peningkatan Pendapatan Asli Daerah dari sektor penerimaan pajak. Namun demikian perbedaan kondisi yang terdapat di wilayah obyek penelitian menjadikan perbedaan atas hasil yang diperoleh, dimana penelitian terdahulu menggunakan 
wilayah yang belum memiliki potensi yang tinggi terkait dengan keberadaan usaha yang menjadi potensi pajak reklame.

\section{KESIMPULAN}

Dari hasil analisis data dan pembahsan yang dilakukan di atas, maka dapat disipulkan antara lain:

1. Implementasi kebijakan pemungutan pajak reklame di Kota Malang didasarkan pada Peraturan Daerah (Perda) Kota Malang dengan menerapkan sistem official assessment, yaitu BPPD Kota Malang melakukan pendataan terlebih dahulu kepada masyarakat yang wajib membayar pajak reklame. Mekanisme pembayaran yang dilakukan oleh wajib pajak dengan membawa blanko SPTPD dan tarifnya ditentukan dari nilai sewa reklame $\mathrm{x}$ tarif pajak reklame. Proses pemungutan pajak reklame Kota Malang dilakukan dengan cara wajib pajak membayar sendiri pajak terutangnya ke loket pembayaran BPPD atau melalui Bank Jatim dengan sistem $e$-tax. Adapun landasan dalam komponen dasar perhitungan tarif pajak reklame yaitu meliputi Nilai Jual Objek Reklame (NJOR), Nilai Strategis Pemasangan Reklame (NS), dan Nilai Sewa Reklame (NSR). Dinas Pendapatan Daerah mengeluarkan kebijakan terkait dengan upaya memaksimalkan pendapatan daerah dari sektor pajak reklame. Pertama kebijakan mengenai intensifikasi yang meliputi pengawasan pembayaran pajak oleh wajib pajak, peningkatan kualitas SDM dan penyusunan peraturan. Kedua, kebijakan terkait dengan ekstensifikasi yaitu mengenai pendataan wajib pajak baru dan sosialisasi pajak reklame.

2. Faktor pendukung penerimaan pajak reklame di Kota Malang yaitu meliputi 1) Sarana dan Prasarana, adanya sarana yang representatif dan nyaman untuk melakukan aktivitas kerja dan adanya dukungan data penerimaan pajak sudah berbasis komputerisasi semua. 2) Sistem informasi yang mendukung yaitu dengan adanya Sistem IT yang telah diterapkan BPPD Kota Malang dalam pengelolaan Pajak Daerah khususnya Pajak Reklame adalah SIMPATDA (Sistem Manajemen Pajak Daerah Antar Bidang), dan E-Tax (Elektronik Tax). 3) Kondisi perekonomian yang semakin membaik yaitu dengan perekonomian masyarakat yang membaik maka daya konsumsi masyarakat akan meningkat pula hal ini membuka peluang usaha yang dilakukan oleh berbagai jenis usaha sehingga peningkatan potensi pada sektor ini dapat terwujud. Faktor Penghambat yaitu meliputi 1) rendahnya kesadaran wajib pajak yang ditunjukkan dengan rendahnya kesadaran wajib pajak untuk memenuhi ketentuan perpajakan yang telah ditetapkan serta tidak pernah mengalami permasalahan hukum terkait dengan masalah pajak. 2) Kualitas Aparatur Dispenda Kota Malang sehingga dalam menjalankan tugas atau pekerjaan belum sesuai dengan ketentuan yang telah ditetapkan. 3) Adanya perubahan sistem media reklame yang digunakan, dimana adanya larangan penggunaan bando jalan (reklame di atas jalan atau tempat penyeberangan dan ditengah jalan) dan harus beralih menggunakan reklame berbentuk videotron sehingga memberatkan bagi wajib pajak dan menolak karena penggunaan alat tersebut mahal dan pajak yang harus dikeluarkan besar.

\section{DAFTAR PUSTAKA}

Kountur, Ronny. 2004. Metode Penelitian. Jakarta: PT. Raya Grafindo Persada.

Laporan Akuntabilitas Kinerja Instansi Pemerintahan Dinas Pendapatan Daerah Kota Malang, 2016. 
JISIP: Jurnal Ilmu Sosial dan IlmuPolitik

ISSN. 2442-6962

Vol. 9 No. 1 (2020)

Miles, Matthew B \& A. Michael Huberman. 2014. Analisis Data Kualitatif: Buku Sumber Tentang Metode-Metode Baru. Jakarta: UI-Press.

Nazir, Moh. 2003. Metode Penelitian. Jakarta: Ghalia Indonesia.

Pebriani, V., \& Rohman, A. (2019). Analisis Inovasi Pelayanan Publik Gesit Aktif Merakyatnya Dinas Kependudukan Dan Pencatatan Sipil (Gampil) Kota Malang. JISIP: Jurnal Ilmu Sosial dan Ilmu Politik, 8(1), 122-128.

Peraturan Daerah (PERDA) Kota Malang Nomor 2 Tahun 2015. Perubahan Atas Peraturan Daerah Kota Malang Nomor 16 Tahun 2010 Tentang Pajak Daerah.

Perwali Malang Nomor 20 Tahun 2013 tentang Tata Cara Pembayaran, Penyetoran, Tempat Pembayaran, Angsuran dan Penundaan Pembayaran Pajak Daerah.

Sripradita, N. A. (2014). Analisis Efektivitas Penerimaan Pajak Reklame dalam Upaya Peningkatan Pendapatan Asli Daerah (Studi pada Dinas Pendapatan Daerah Kabupaten Kediri). Jurnal Mahasiswa Perpajakan, 1(1).

Undang-Undang Nomor 32 Tahun 2004 tentang Pemerintahan Daerah.

Undang-Undang Nomor 34 Tahun 2000 tentang Perubahan atas Undang-undang Republik Indonesia No. 18 tahun 1997 tentang Pajak dan Retribusi Daerah.

Undang-Undang Nomor 9 Tahun 2015 tentang Pemerintahan Daerah.

Zuraida, Ida. 2012. Teknik Penyusunan Peraturan Daerah. Jakarta: Sinar Grafika. 